\title{
PI3K Abrogation Using Pan-PI3K Inhibitor BKM120 Gives Rise to a Significant Anticancer Effect on AML-Derived KG-1 Cells by Inducing Apoptosis and G2/M Arrest
}

\author{
Pan-PI3K Inhibitörü BKM120 Kullanılarak PI3K Inhibisyonu Apopitoz ve G2/M Fazında \\ Durma Yoluyla AML-kökenli KG-1 Hücrelerinde Antikanser Etkiyi Anlamlı Artırır
}

\begin{abstract}
(D) Soroush Sadeghi1, (D) Shadi Esmaeili2, (D) Atieh Pourbagheri-Sigaroodi2, (D) Ava Safaroghli-Azar2, (D) Davood Bashash1
${ }^{1}$ Department of Hematology and Blood Banking, School of Allied Medical Sciences, Shahid Beheshti University of Medical Sciences, Tehran, Iran 2Student Research Committee, Department of Hematology and Blood Banking, School of Allied Medical Sciences, Shahid Beheshti University of Medical Sciences, Tehran, Iran
\end{abstract}

\section{Abstract}

Objective: The association between PI3K overexpression and the acquisition of chemoresistance has attracted tremendous attention to this axis as an appealing target to revolutionize the conventional treatment strategies of human cancers. In the present study, we aimed to survey the inhibitory impact of the pan-PI3K inhibitor BKM120 on both cellular and molecular aspects of acute myeloid leukemia (AML)-derived KG-1 and U937 cells.

Materials and Methods: We designed various assays to survey the antitumor impacts and molecular mechanisms underlying the action of BKM120 for the treatment of AML, and we performed experiments to check the effect of BKM120 in combination with idarubicin.

Results: We found that PI3K inhibition diminished cell viability and metabolic activity and exerted a concentration-dependent growthsuppressive effect on the cells. Moreover, we suggested that the ability of BKM120 to induce its antiproliferative properties was mediated through the induction of p21-mediated G2/M cell-cycle arrest. Investigating the effect of inhibitor on the molecular features revealed not only that $\mathrm{BKM} 120$ reduced the expression of NF- $\mathrm{KB}$ antiapoptotic targets, but also that NF- $\kappa B$ suppression using bortezomib profoundly enhanced the cytotoxicity of the inhibitor, highlighting that the antileukemic effects of BKM120 are mediated, at least partly, through the modulation of the NF- $\kappa B$ pathway. Interestingly, we found that the single agent of BKM120 was unable to significantly alter the expression level of $\mathrm{c}-\mathrm{Myc}$; however, the capability of BKM120 to reduce the survival rate of $A M L$ cells was potentiated upon c-Myc inhibition using 10058-F4, suggestive of the plausible contribution of c-Myc in leukemic cell response to the PI3K inhibitor.

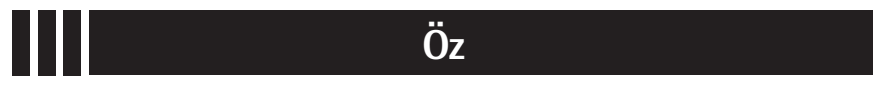

Amaç: PI3K aşırı ifadesi ile kemoterapiye direnç kazanııması arasındaki ilişki insan kanserlerinin konvansiyonel tedavi stratejilerinde devrim yaratmak yolunda cazip bir hedef oluşturarak bu yolağa olan ilgiyi büyük ölçüde artırmıştır. Bu çalışmamızda pan-PI3K inhibitörü BKM120'nin akut myeloid lösemi (AML) kökenli KG-1 ve U937 hücreleri üzerine hücresel ve moleküler inhibitor etkisini araştırmayı amaçladık.

Gereç ve Yöntemler: AML tedavisinde BKM120'nin etkisinin altında yatan moleküler mekanizmalar ve antitümör tesirini araştırmak için çeşitli yöntemler oluşturduk ve BKM120 idarubisin kombinasyonunun etkisini kontrol etmek için deneyler yaptık.

Bulgular: PI3K inhibisyonunun hücre canlılığı ve metabolik aktiviteyi azalttığını ve hücrelerde konsantrasyona bağımlı olarak büyümeyi baskılayıcı etki gösterdiğini bulduk. Ayrıca, BKM120'nin antiproliferatif etkilerini p21 aracılı G2/M hücre döngüsünü durdurmak yoluyla gösterdiğini ileri sürdük. İnhibitörün moleküler özellikler üzerindeki etkisinin araştırılması sadece BKM120'nin antiapoptotik NF-KB'nin hedeflerinin ifadesini azalttığını değil, fakat aynı zamanda bortezomib

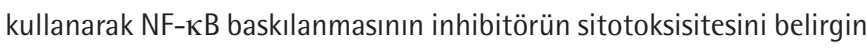
artırdığını ortaya koyarak BKM120'nin antilösemik etkisinin en azından kısmen NF-кB yolağı modülasyonuyla olduğunu gösterdi. İlginç olarak, tek başına BKM120'nin c-Myc ifadesini anlamlı değiştiremediği, ancak BKM120'nin AML hücrelerinin sağkalım oranlarını azaltma kapasitesinin 10058-F4 aracılı c-Myc inhibisyonu ile artması lösemik hücrelerde c-Myc'nin PI3K inhibitörüne yanıta katkıda bulunduğunu düşündürmektedir.

๑Copyright 2020 by Turkish Society of Hematology

Turkish Journal of Hematology, Published by Galenos Publishing House

Adress for Correspondence/Yazışma Adresi: Davood Bashash, PhD, Department of Hematology and Blood Banking,

School of Allied Medical Sciences, Shahid Beheshti University of Medical Sciences, Tehran, Iran

Phone : +98-21-22717504

E-mail : d.bashash@sbmu.ac.ir ORCID: orcid.org/0000-0002-8029-4920 


\section{Abstract}

Conclusion: Taken together, the results of this study reveal the efficacy of BKM120 as a therapeutic approach for AML; however, further investigations should be undertaken to determine the expediency of this inhibitor.

Keywords: Acute myeloid leukemia, KG-1 cell, BKM120, PI3K inhibition, NF- $\mathrm{KB}, \mathrm{c}-\mathrm{Myc}$
$\ddot{\mathrm{O} z}$

Sonuç: Birlikte değerlendirildiğinde bu çalışmanın sonuçları AML için terapötik yaklaşımda BKM120'nin etkililiğini göstermektedir. Ancak bu inhibitörün uygunluğunu belirlemek için ek çalışmalar yapılmalıdır.

Anahtar Sözcükler: Akut myeloid lösemi, KG-1 hücresi, BKM120, PI3K inhibisyonu, NF-KB, c-Myc

\section{Introduction}

Following the comprehension of the important oncogenic pathways that participate in cancer progression, it has become clear that the principal components of these networks will likely act as effective factors in the landscape of anticancer drug design [1]. Among these molecules, phosphatidylinositol 4,5-bisphosphate 3-kinase (PI3K) is currently being explored and the data achieved so far for this protein and its associated network have already translated into novel targeted therapies in the quest for cancer-treatment strategies [2,3]. The recognition that PI3K signaling was aberrantly activated in acute myeloid leukemia (AML) owing to somatic mutations in PIK3Ca, along with the core function of this axis in forcing leukemic cell resistance to apoptosis, paved the way for the recognition of $\mathrm{PI3K}$ inhibitors as key elements in the field of AML therapy [4].

Its prominent properties, minor side effects, desirable pharmacokinetic patterns, and broad anticancer impacts on various malignant cells have gained BKM120, a bioavailable specific oral pan-class I PI3K inhibitor, the highest attention among other inhibitors of this pathway $[5,6]$. In a study conducted by Yang et al. [7], it was illustrated that not only could BKM120 hinder colon cancer cell proliferation through Fox03adependent PUMA induction, but it also potentiated the effect of either 5-fluorouracil or regorafenib on different colon cancerderived cell lines. Additionally, in vivo investigation revealed that oral administration of BKM120 to cholangiocarcinomainoculated nude mice resulted in tumor growth reduction as compared to the control group [8]. The importance of this agent was further revealed in a recent study that demonstrated that abrogation of PI3K using pan-PI3K inhibitor BKM120 decreased the survival of multiple myeloma cells via induction of caspase-3dependent apoptosis, and it also produced a synergic anticancer effect when combined with carfilzomib [9]. While data obtained from these clinical trials and laboratory assays have illustrated the notable impacts of this inhibitor, further surveys are being performed to accurately identify the molecular mechanisms of action of BKM120. Therefore, with the intention of evaluating the potential therapeutic value of pan-PI3K inhibition in AML, we have designed various assays to survey the antitumor impacts and molecular mechanisms underlying the action of BKM120 for treatment of AML. To study the potential therapeutic value of the inhibitor's cooperation with chemotherapeutic drugs, we also performed experiments to determine the effect of BKM120 in combination with idarubicin, with the end goal of potentiating its effect on AML-derived KG-1 cells.

\section{Materials and Methods}

\section{Cell Culture}

KG-1 and U937 cells were grown in RPMI 1640 medium with $10 \%$ fetal bovine serum and $2 \mathrm{mM}$ L-glutamine in a humidified $5 \% \mathrm{CO}_{2}$ atmosphere at $37{ }^{\circ} \mathrm{C}$. Stock solutions of BKM120, idelalisib, 10058-F4, bortezomib (Selleckchem), idarubicin, and chloroquine ( $\mathrm{CO}$ ) were provided. AML-derived cells were incubated with the desired concentrations of each agent either alone or in a combined modality. For a negative control, cells were treated with equal concentrations of the solvent.

\section{Trypan Blue Staining Assay}

AML-derived cell lines were treated with either BKM120 alone or co-treatment with the aforementioned inhibitors and the chemotherapeutic drug. After the indicated time duration, trypan blue (Invitrogen) was added to the inhibitor-treated cell mixtures, which were then incubated for approximately $2 \mathrm{~min}$. The numbers of viable cells were calculated using a Neubauer hemocytometer and then the viability index was determined.

\section{MTT Assay}

With the aim of evaluating the antileukemic effects of BKM120, idelalisib, and 10058-F4 on the AML-derived cells, the MTT assay was applied. The cells $\left(5 \times 10^{3}\right)$ were seeded in 96 -well plates in the presence of the inhibitors and incubated in a humidified $5 \% \mathrm{CO}_{2}$ incubator at $37{ }^{\circ} \mathrm{C}$. At different time intervals, the MTT solution $5 \mathrm{mg} / \mathrm{mL}$ in phosphate buffered saline (PBS)] was added to each well and incubated for $3 \mathrm{~h}$ at $37^{\circ} \mathrm{C}$. After discarding the media, the percentage of the metabolic activity of cells was evaluated by dividing the optical density (OD) of resulting formazan measured by an enzyme-linked immunosorbent assay (ELISA) reader in the drug-treated groups by the OD of the control group. 


\section{Acridine Orange Staining Assay}

To investigate the contributory role of autophagy in BKM120 cytotoxicity on KG-1, the cells were treated with increasing concentrations of the autophagy inhibitor CO (Sigma). The cells were then washed with PBS and dyed with $1 \mu \mathrm{g} / \mathrm{mL}$ acridine orange (Merck) for $15 \mathrm{~min}$ in the dark. The differences in acidity of autophagic lysosomes and the cytoplasm/nucleolus were visualized under a fluorescence microscope and by flow cytometry (BD FACSCalibur, BD Biosciences, San Jose, CA, USA).

\section{BrdU Cell Proliferation Assay}

To assess the inhibitory effects of BKM120 on DNA synthesis, the 5-bromo-2-deoxyuridine cell proliferation assay was performed using an ELISA kit (Roche, Mannheim, Germany) based on the manufacturer's guidelines [10].

\section{Real-Time PCR (RNA Extraction and cDNA Synthesis)}

In order to extract total RNA from the KG-1 cell line, the High Pure RNA Isolation Kit (Roche, Mannheim, Germany) was used and results were quantified spectrophotometrically with a NanoDrop device (NanoDrop Technologies, Wilmington, DE, USA). Afterwards, a cDNA synthesis kit (Takara Bio, Shiga, Japan) was used to perform reverse transcription reactions. The cDNA was subjected to quantitative real-time PCR (qRT-PCR) and then fold change values were calculated based on the $2^{-\Delta \Delta c t}$ relative expression formula. $A B L$ was amplified as a housekeeping gene. The sequences of primers used in the experiment are summarized in Table 1.

\section{Flow Cytometric Analysis of Apoptosis and Cell Cycle}

The effects of BKM120 on the programmed cell death and progression of the cell cycle were evaluated by annexin- $V$ staining assay in AML-derived cells. BKM120-treated cells were harvested after $48 \mathrm{~h}$ of treatment, washed with PBS, and subjected to flow cytometric analysis of annexin- $\mathrm{V}$ and $\mathrm{PI}$ staining assays as described in our previous study [11].

\section{Statistical Analysis}

Our data are presented as the mean \pm standard deviation (SD) $(p<0.05)$ of three individual experiments; all experiments were carried out in triplicate. Differences among experimental variables were determined by the use of Student's t-test, employing SPSS and dne-way analysis of variance.

\section{Results}

\section{Cytotoxic Effects of PI3K Inhibitors on AML-Derived KG-1 Cells}

To investigate the cytotoxic effects of the pan-PI3K inhibitor BKM120 on AML, KG-1 cells were incubated with various concentrations of the inhibitor, and then the MTT assay was applied. Our results suggested that upon PI3K inhibition the metabolic activity of the KG-1 cell line was diminished in a concentration-dependent manner (Figure 1A). To validate the cytotoxic effects of PI3K inhibition on this cell line, we also assessed the effects of idelalisib, a highly selective inhibitor of the $\mathrm{PI} 3 \mathrm{~K}$ p $110-\delta$ isoform. In agreement with the results obtained for BKM120, it was evident that exposure of the cells to idelalisib resulted in a clear decline in the survival rate of the cells (Figure 1B). Our supplementary experiments investigating the effects of PI3K inhibition on AML further confirmed the cytotoxic effect of BKM120 on AML-derived U937 cells (Figure 1C).

\section{Antiproliferative Effects of BKM120 on KG-1 Cells Are Mediated Through the Induction of G2/M Arrest}

Multiple lines of evidence have revealed that the PI3K signaling pathway is tightly associated with a diverse group of cellular functions, including cell proliferation and DNA synthesis [12]. Our results demonstrated that the treatment of the cells with this pan-PI3K inhibitor not only decreased the DNA synthesis rate but also inhibited the proliferative capacity of the cells, as revealed by the reduction in the number of viable cells (Figure $2 \mathrm{~A})$. Moreover, the cell population in the $S$ phase was decreased from $37.2 \%$ in the control group to $22.4 \%$ in the $4 \mu \mathrm{M}$-treated cells (Figure 2B). Meanwhile, the percentage of cells in the G2/M

\begin{tabular}{|c|c|c|c|}
\hline Gene & Forward primer $\left(5^{\prime}-3^{\prime}\right)$ & Reverse primer $\left(5^{\prime}-3^{\prime}\right)$ & Size (bp) \\
\hline$A B L$ & CTGAAGCTGGTGGGCTGCAAATC & CACTCAGACCCTGAGGCTCAAAG & 115 \\
\hline$p 21$ & СCTGTCACTGTCTTGTACCCT & GCGTTGGAGTGGTAGAAATCT & 130 \\
\hline$p 27$ & AACGTGCGAGTGTCTAACGG & СССTCTAGGGGTTTGTGATTCT & 209 \\
\hline$B c /-2$ & GTGAAGCAGAAGTCTGGGAATCG & ACAAATGCATAAGGCAACGATCC & 145 \\
\hline Survivin & CCAGATGACGACCCCATAGAG & ПTGTGGTTCCПTGCAAПTा & 152 \\
\hline$c-M y c$ & CCACAGCAAACCTCCTCACAG & GCAGGATAGTCCTTCCGAGTG & 105 \\
\hline Pin1 & ATCACTAACGCCAGCCAGTGGG & TGGATGTAGCCGTTGATCAGCTC & 200 \\
\hline Bax & CGAGAGGTCIIITCCGAGTG & GTGGGCGTCCCAAAGTAGG & 242 \\
\hline FOXO3a & TGCTCACTTCGGACTCAC & GGACATCATCGGATCATTGC & 137 \\
\hline
\end{tabular}


phase of the cell cycle grew by nearly 10 -fold in comparison with the control group, suggesting that the antiproliferative effects of the agent on KG-1 are mediated, at least partly, by the induction of $\mathrm{G} 2 / \mathrm{M}$ arrest.

\section{Stimulatory Effect of c-Myc Suppression on BKM120-Induced Cytotoxicity in KG-1 Cells}

Growing numbers of experiments reveal that, upon PI3K signaling, $c-M y c$ is activated and subsequently drives the cell cycle through the suppression of p21 and p27 $[13,14]$. We found that BKM120 upregulated the mRNA expressions of both $\mathrm{p} 21$ and p27; however, we could find no significant alteration in $c-M y c$ level (Figure 3A). It has been reported that the unrestrained
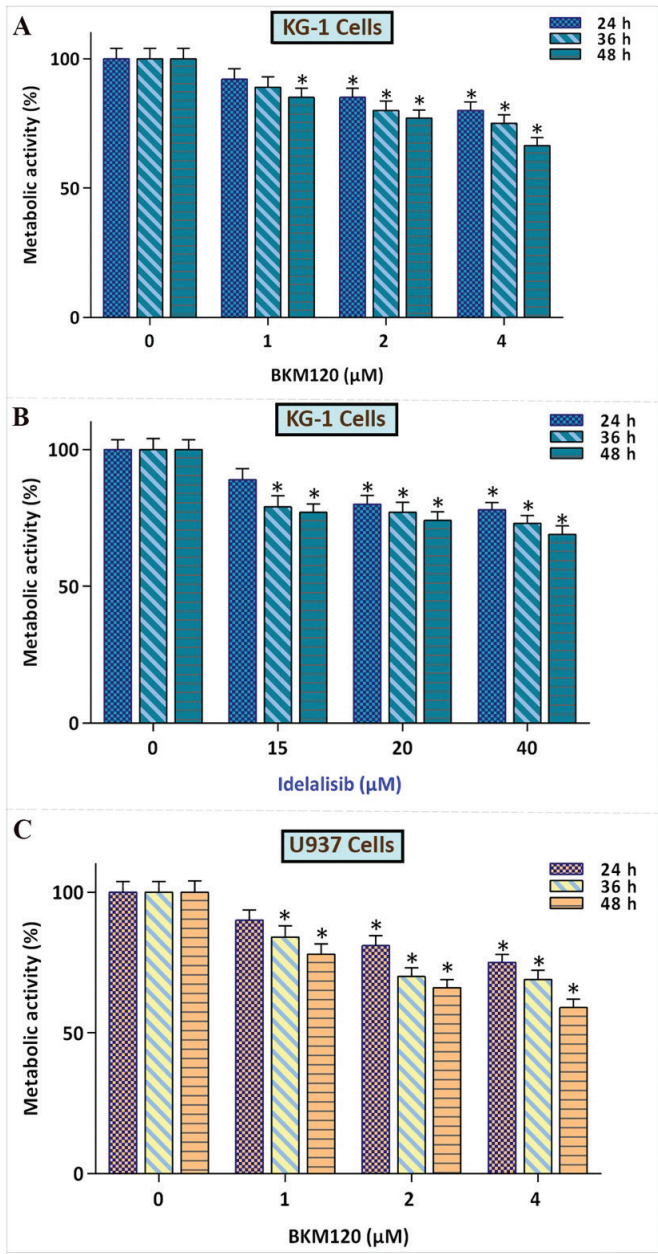

Figure 1. Cytotoxic effect of PI3K inhibitors BKM120 on AMLderived cells. A and B) Suppression of the PI3K signaling pathway using BKM120 and idelalisib reduced the metabolic activity of KG-1 cells. C) In agreement with the results for KG-1, BKM120 also decreased the survival of U937 cells. Values are given as mean \pm SD of three independent experiments. ${ }^{*}: p \leq 0.05$ represents significant changes from the untreated control. ANOVA was used to compare the mean of the metabolic activity tests.

SD: Standard deviation, AML: acute myloid leukemia. activation of c-Myc could be directly responsible for the lower sensitivity of malignant cells to PI3K inhibitors [15]. Accordingly, we found that the suppression of c-Myc using 10058-F4 not only reduced KG-1 cell survival (Figure $3 \mathrm{~B}$ ) but also boosted the cytotoxic effects of either BKM120 or idelalisib when used in a combined-modality treatment (Figure 3C). Complementary investigations also confirmed that co-treatment of U937 cells with BKM120 and 10058-F4 resulted in superior cytotoxicity as compared to each drug alone (Figure 3D).

\section{BKM120 Induced Apoptotic Cell Death in AML-Derived KG-1 Cells}

The PI3K pathway affects a notable array of intracellular events that directly or indirectly influence whether a cell will undergo apoptosis $[16,17,18]$. Our results showed that the amounts of annexin- $V$ cells were elevated in comparison with the control group, which is in agreement with the augmented cells in the sub-G1 phase (Figure 4A). Numerous studies have demonstrated that the alteration of the autophagy system may act as an important contributory mechanism affecting the extent of cell death induced by anticancer agents in malignant cells $[19,20,21]$. To investigate the contributory role of autophagy in BKM120 cytotoxicity, the effect of CO, a well-known autophagy inhibitor, was examined as both a single agent and in combination with the PI3K inhibitor. Our results showed that the inhibition of autophagy, as revealed by a concentrationdependent reduction in the fluorescence intensity ratio detected by either microscopic imaging or flow cytometric analysis, did not induce a stimulatory effect on BKM120's anticancer effect (Figure 4B).

\section{Alteration of Apoptosis-Related Genes Upon Treatment of KG-1 Cells with BKM120}

Multiple line of evidence revealed that a fine-tuned balance between pro- and antiapoptotic target genes determines the receptiveness of cancer cells to death stimuli $[22,23]$. Our results showed that BKM120 upregulated the mRNA expressions of proapoptotic genes and diminished the transcription of antiapoptotic target genes of NF- $\kappa B$ (Figure $5 \mathrm{~A}$ ). Based on our findings and with reference to the considerable studies pointing to the tight crosstalk between NF- $\kappa B$ and the PI3K pathway [24], we examined the effect of NF- $\mathrm{KB}$ suppression on the anticancer impact of the inhibitor. Our results showed that the suppression

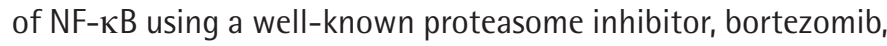
amplified the repressive effect of the PI3K inhibition on KG-1 cell survival (Figure 5B).

\section{Synergistic Effect of BKM120 with Idarubicin in AML-Derived KG-1 Cells}

As shown in Figure $6 \mathrm{~A}$, the combination of BKM120 at a concentration of $4 \mu \mathrm{M}$ with idarubicin (175 and $200 \mathrm{nM}$ ) was more effective in inhibiting cell growth and survival as 
compared to either drug alone. To test whether the interactions between these drugs were synergistic or caused by additive effect, the combination index $(\mathrm{Cl})$ and isobologram were calculated. Determination of both $\mathrm{Cl}$ and dose reduction index (DRI) values clarified that, unlike the lower concentration of
BKM120 $(2 \mu \mathrm{M})$, the higher concentration of this agent has the ability to boost the cytotoxic and antiproliferative effects of this well-known chemotherapeutic drug used in AML treatment protocols (Figure 6B). Values of $\mathrm{Cl}$ and DRI achieved after $24 \mathrm{~h}$ of treatment of KG-1 cells are summarized in Table 2.

A
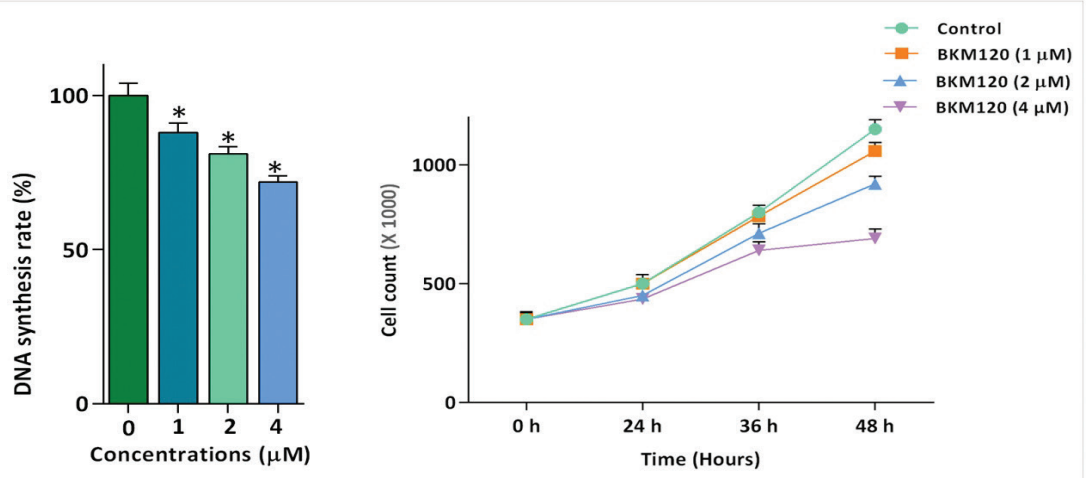

B
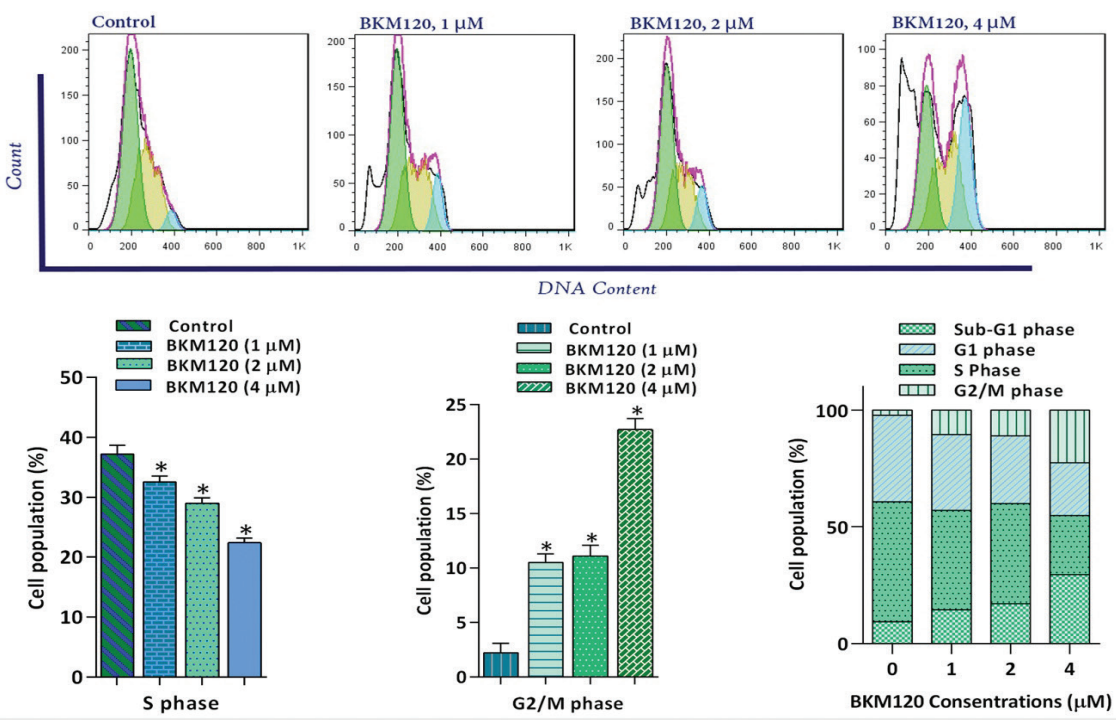

Figure 2. BKM120's effect on the proliferative capacity of KG-1 cells. A) The ability of BKM120 to blunt the capability of the cells to replicate their DNA and to proliferate was assessed using BrdU and trypan blue exclusion assays, respectively. B) Evaluating the effect of the agent on the distribution of cells in different phases of the cell cycle revealed that BKM120 halted the transition of cells from the $\mathrm{G} 2 / \mathrm{M}$ phase as well as reducing the percentage of cells in the $\mathrm{S}$ phase of the cell cycle after $48 \mathrm{~h}$ of treatment. Values are given as mean \pm SD of three independent experiments. * $p \leq 0.05$ represents significant changes from the untreated control. ANOVA was used for statistical analysis.

SD: Standard deviation.

\begin{tabular}{|c|c|c|c|c|}
\hline \multicolumn{5}{|l|}{$24 h$} \\
\hline \multicolumn{2}{|l|}{ BKM120 } & \multicolumn{2}{|l|}{ Idarubicin } & \multirow{2}{*}{$\mathrm{Cl}$} \\
\hline Concentration $(\mu \mathrm{M})$ & DRI & Concentration (nM) & DRI & \\
\hline 2 & 5.26 & 175 & 1.16 & 1.051 \\
\hline 4 & 15.17 & 175 & 1.52 & 0.722 \\
\hline 2 & 9.16 & 200 & 1.10 & 1.012 \\
\hline 4 & 19.90 & 200 & 1.38 & 0.770 \\
\hline
\end{tabular}



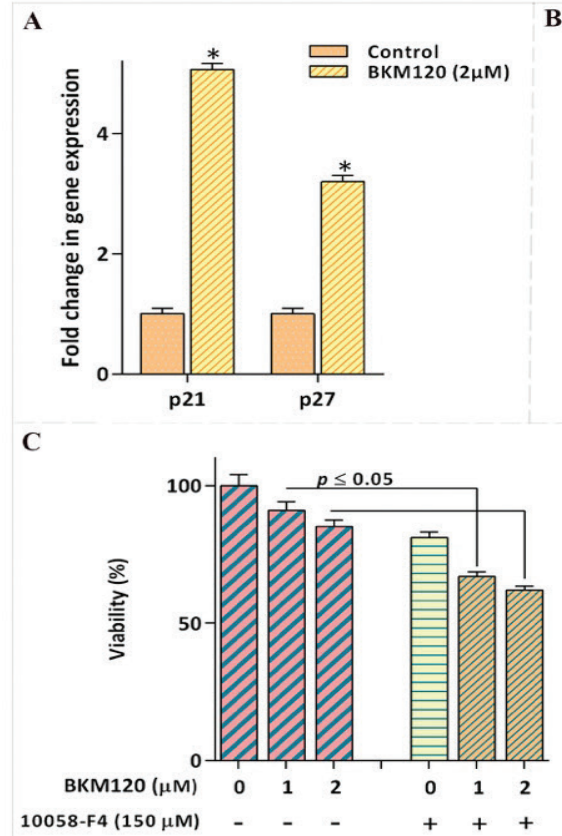
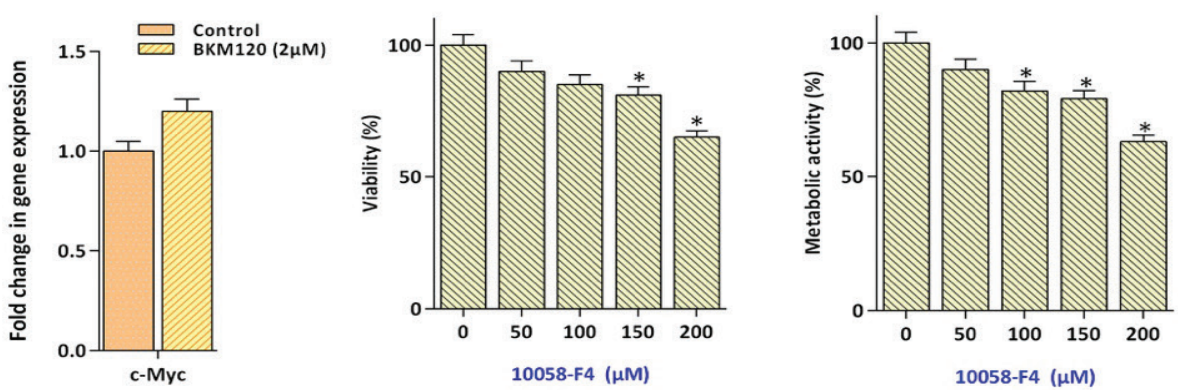

D

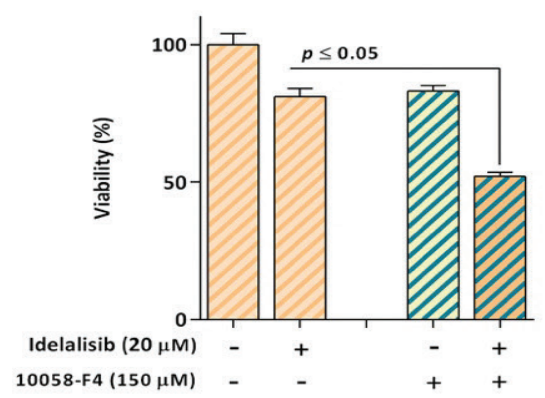

Figure 3. c-Myc abrogation potentiated the cytotoxic effect of both BKM120 and idelalisib in KG-1 and U937 cells. A) Treatment of KG-1 cells with BKM120 escalated the expression levels of p21 and p27. B) Although BKM120 could not significantly alter the mRNA expression level of c-Myc, its inhibition using 10058-F4 decreased the viability and metabolic activity of KG-1 cells (the significance of the results was evaluated by the use of ANOVA). The endogenous gene used in the experiments was $A B L$. Values are given as mean \pm SD of three independent experiments. *: $p \leq 0.05$ represents significant changes from the untreated control. C) Upon $24 \mathrm{~h}$ of exposure to the c-Myc inhibitor, the antileukemic effects of both PI3K inhibitors were reinforced in AML-derived cell lines. D) Synergistic effect of BKM120 and 10058-F4 on U937 cells indicated the same result. The t-test was used to determine the statistical significance of the results of qRT-PCR analysis as well as synergistic experiments.

SD: Standard deviation, RT-PCR: reverse transcription-polymerase chain reaction.

\section{Discussion}

With the increasing comprehension of the molecular mechanisms underlying human cancers and the recent achievements in understanding the events connected to tumor cells' responses to chemotherapeutic drugs, cancer treatment procedures have changed substantially [25]. Adequate laboratory studies demonstrated that the overactivation of the PI3K network is not only associated with cancer progression, but also results in the acquisition of a chemoresistance phenotype [26,27]. It has also been reported that the aberrant activation of PI3K is coupled with poor prognosis in a variety of human malignancies, including AML [28]. Our data have revealed that the suppression of PI3K using BKM120 could remarkably reduce both the survival and the metabolic activity of the AML-derived KG-1 and U937 cell lines, which is in agreement with the results reported by Allegretti et al. [29], who showed a favorable antileukemic effect of the inhibitor against AML cells but not the normal counterpart. In addition, Pillinger et al. [30] revealed that PI3K inhibition using three PI3K inhibitors, LY294002, IPI-145, and CAL-101, significantly reduced the survival of AML cells in vitro or in vivo. In harmony with the results for BKM120, treatment with the isoform-specific PI3K $\delta$ inhibitor idelalisib further confirmed the cytotoxic effects of PI3K inhibition in KG-1 and U937 cells. Additionally, PI3K suppression potentially reinforced the antileukemic property of a commonly used chemotherapeutic drug in AML treatment, idarubicin, highlighting the promising effect of the inhibitor either as a single agent or in combinedmodality treatment.

In light of the growth-suppressive effects of PI3K inhibitors on tumor cells and based on the central role of this network in the progression of the cell cycle [31], the effect of the agent on cell distribution was examined using flow cytometric analysis. Our results demonstrated that the treatment of KG-1 with BKM120 not only inhibited proliferative capacity by reducing DNA replication and the number of viable cells but also led to an increased percentage of cells in the G2/M phase, suggesting that the antiproliferative effects of the inhibitor are mediated, at least partially, through the induction of G2/M arrest. In an investigation of the effects of PI3K suppression on multiple myeloma cells, the inhibitory effect of pan-PI3K inhibition on the survival of both KMM-1 and RPMI 8226 cells via the induction of SIRT1-mediated G2/M arrest was also highlighted [9]. Additionally, Xie et al. [32] showed that puquitinib, an orally available $\mathrm{PI} 3 \mathrm{~K} \delta$ inhibitor, hindered the proliferative capacity of 
AML-derived cell lines through induction of $\mathrm{G} 1$ cell-cycle arrest. Among examples of overactivation of malignant signaling networks, and foremost of the PI3K pathway, the c-Myc oncogene is explicitly activated and subsequently leads to cell cycle progression via the inhibition of cell cycle-related genes such as p21 and p27 cyclin-dependent kinase inhibitors [33]. Remarkably, while BKM120-induced G2/M arrest was associated with the upregulation of $\mathrm{p} 21$ and $\mathrm{p} 27$ expression, we could find no noticeable alteration in c-Myc mRNA levels, suggesting
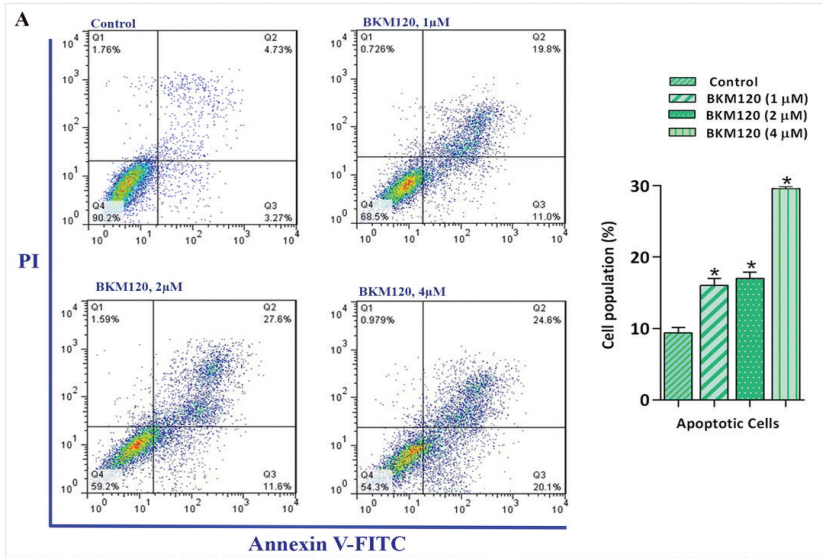

B
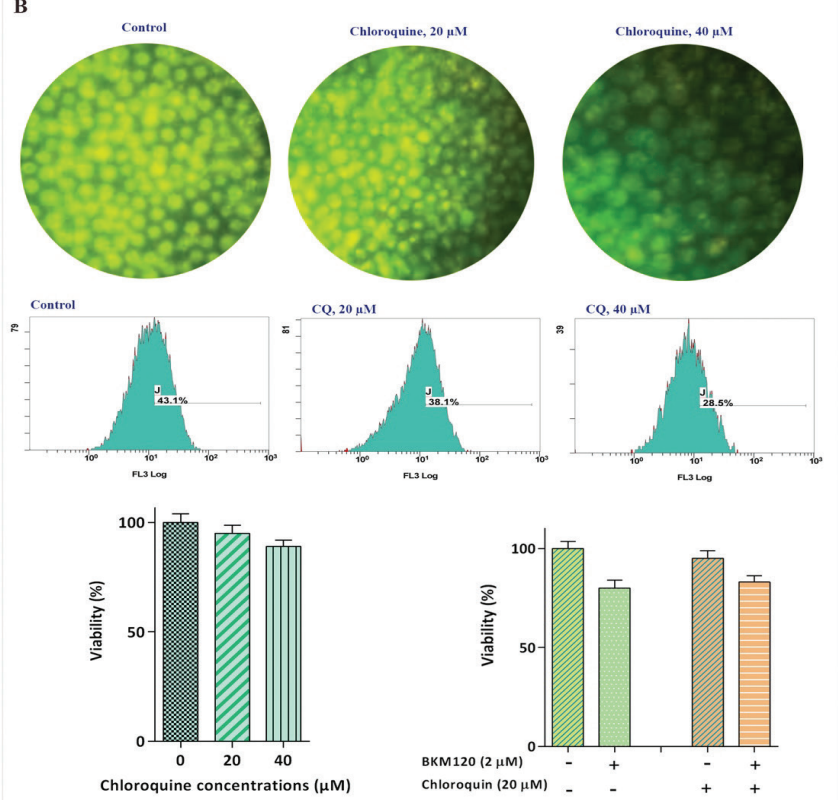

Figure 4. BKM120 exerted its cytotoxic effect partly through induction of apoptosis. A) The percentage of annexin-V-positive inhibitor-treated cells was elevated after $48 \mathrm{~h}$ of treatment with BKM120 as compared to the untreated group. The ANOVA test was used to determine the statistical significance of the results of flow cytometry analysis. B) The inhibition of autophagy, as represented by a reduction of fluorescence intensity, could not induce a significant stimulatory effect on BKM120's anticancer effect. Values are given as mean \pm SD of three independent experiments. ${ }^{*}: p \leq 0.05$ represents significant changes from the untreated control.

SD: Standard deviation. the probable contribution of the $c-M y c$ oncogene with less sensitivity of leukemic cells to the PI3K inhibitors. Accordingly, investigation of the effects of the small-molecule inhibitor of c-Myc revealed that 10058-F4 reduced KG-1 cell survival and
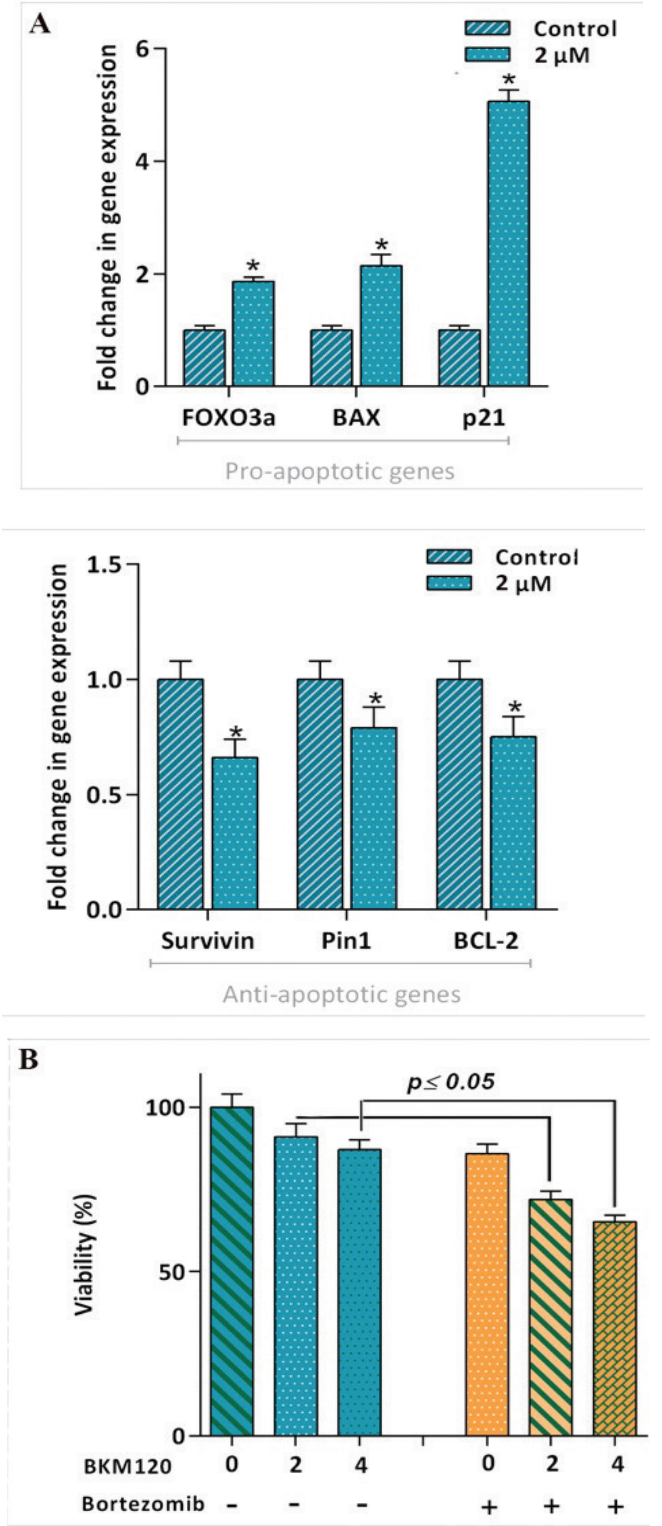

Figure 5. BKM120 altered the expression of apoptosis-related genes. A) After $48 \mathrm{~h}$ of treatment of the cells with BKM120 at a concentration of $2 \mu \mathrm{M}$, the expression levels of pro- and antiapoptotic genes were determined using qRT-PCR. The inhibitor could not only increase the expression of proapoptotic genes but could also diminish the mRNA expression levels of antiapoptotic genes. $A B L$ was used as an endogenous gene. B) Proteasome inhibitor bortezomib potentiated the effect of BKM120 in KG-1 cells. Values are given as mean \pm SD of three independent experiments. ${ }^{*}: p \leq 0.05$ represents significant changes from the untreated control. The t-test was used to determine the statistical significance of the results of qRT-PCR analysis as well as synergistic experiments.

SD: Standard deviation, RT-PCR: reverse transcription-polymerase chain reaction. 
A

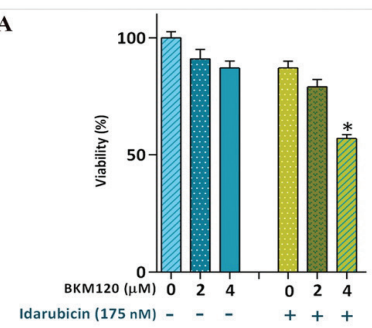

B

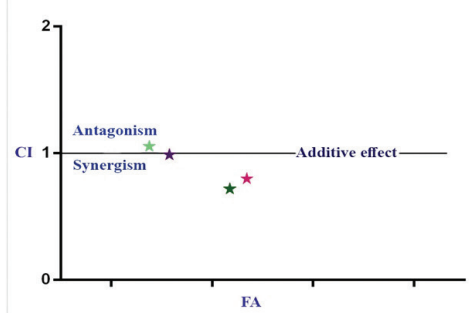

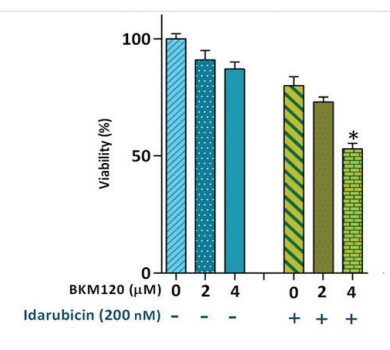

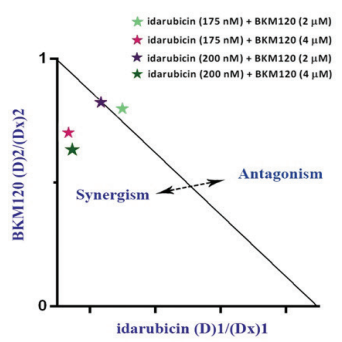

Figure 6. BKM120 and idarubicin co-treatment resulted in superior cytotoxicity in KG-1 cells. A) BKM120 could potentiate the antileukemic effect of idarubicin on AML-derived cell lines. B) The results of both the combination index $(\mathrm{CI})$ and isobologram highlight the synergistic effect between BKM120 and idarubicin. Values are given as mean \pm SD of three independent experiments. *: $\mathrm{p} \leq 0.05$ represents significant changes from the untreated control. The t-test was used to determine the statistical significance of the results of synergistic experiments.

SD: Standard deviation, AML: acute myloid leukemia.

sensitized the cells to lower concentrations of either BKM120 or idelalisib, supporting our hypothesis that the c-Myc inhibitors may restore leukemic cell sensitivity to PI3K inhibitors when administered as part of combination regimens.

Extensive experiments have revealed an alternative mechanism through which p21 could induce apoptotic cell death through modulation of the NF-KB pathway [34]. Moreover, the contributing role of $\mathrm{NF}-\mathrm{KB}$ in the mechanism of action of several chemotherapeutic drugs has been clearly established in several reports [35]. Our results showed that the antileukemic property of BKM120 was not only remarkably coupled with the reduction in the expression levels of NF- $\kappa B$ antiapoptotic target genes; additionally, NF- $\kappa B$ suppression using the well-known proteasome inhibitor bortezomib could profoundly enhance the cytotoxic effect of BKM120 on KG-1 cells, substantiating the claim that the antileukemic effects of the inhibitor are mediated, at least partly, through modulation of the NF- $\kappa B$ pathway. The results of previous studies suggested that NF- $\kappa B$ could provide a signal that in turn could activate the autophagy system in cancerous cells and thereby attenuate death signals [36]. Of particular interest, we found that the antitumor effect of BKM120 was not influenced by the inhibition of autophagy and, as far as we are aware, our results suggest for the first that the induction of cell death in KG-1 cells is probably mediated independently of the autophagy system (Figure 7).

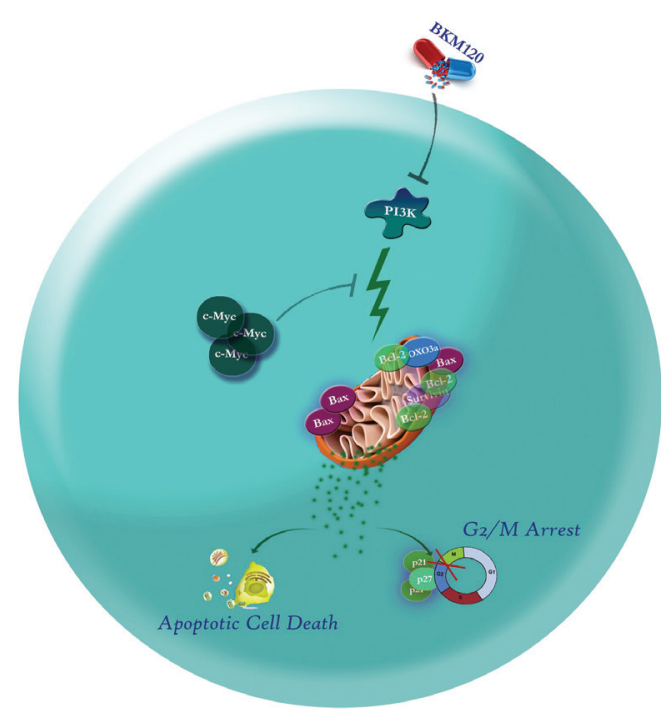

Figure 7. Schematic representation suggested for the plausible mechanisms of action of BKM120 in KG-1 cells. Via abrogation of the PI3K signaling pathway, BKM120 diminished the survival and proliferative capacity of the cells, possibly through escalation of cyclin-dependent kinase inhibitors p21 and p27 and subsequent $\mathrm{G} 2 / \mathrm{M}$ arrest. As presented, suppression of PI3K induced apoptotic cell death through upregulation of proapoptotic genes and downregulation of antiapoptotic genes, which may, at least in part, be overshadowed by the activation of c-Myc expression.

\section{Conclusion}

Taken together, the results of the present study show that BKM120 is a favorable anticancer agent, either as a single agent or in a combined-modality strategy in cancer therapeutics; however, further investigations should be undertaken to determine the suitability of the inhibitor, in particular for the treatment of AML.

\section{Acknowledgments}

The authors would like to express their gratitude to Shahid Beheshti University of Medical Sciences (Tehran, Iran) for supporting and funding this study.

\section{Ethics}

Ethics Committee Approval: This article does not contain any studies with human participants or animals performed by any of the authors.

Informed Consent: Our study does not contain any studies with human participants or animals performed by any of the authors.

\section{Authorship Contributions}

Concept: D.B.; Data Collection or Processing: S.S., S.E., A.P.S.; Writing: A.P.S., A.S.A., D.B. 
Conflict of Interest: No conflict of interest was declared by the authors.

Financial Disclosure: The authors declared that this study received no financial support.

\section{References}

1. Croce $\mathrm{CM}$, Zhang $\mathrm{K}$, Wei $\mathrm{YQ}$. Announcing signal transduction and targeted therapy. Signal Transduct Target Ther 2016;1:15006.

2. Kalra M, Nakshatri H. Will PI3K-targeted therapies for cancer become a reality? Transl Cancer Res 2017;6:371-375.

3. Fruman DA, Rommel C. PI3K and cancer: lessons, challenges and opportunities. Nat Rev Drug Discov 2014;13:140-156.

4. Khwaja A. PI3K as a target for therapy in haematological malignancies. Curr Top Microbiol Immunol 2010;347:169-188.

5. Baselga J, Im SA, Iwata $H$, Cortés J, De Laurentiis $M$, Jiang $Z$, Arteaga $C L$, Jonat W, Clemons $M$, Ito $Y$, Awada A, Chia S, Jagiełło-Gruszfeld A, Pistilli B, Tseng LM, Hurvitz S, Masuda N, Takahashi M, Vuylsteke P, Hachemi S, Dharan B, Di Tomaso E, Urban P, Massacesi C, Campone M. Buparlisib plus fulvestrant versus placebo plus fulvestrant in postmenopausal, hormone receptor-positive, HER2-negative, advanced breast cancer (BELLE-2): a randomised, double-blind, placebo-controlled, phase 3 trial. Lancet Oncol 2017;18:904-916.

6. Pistilli B, Pluard T, Urruticoechea A, Farci D, Kong A, Bachelot T, Chan S, Han $H S$, Jerusalem G, Urban P, Robinson D, Mouhaër SL, Tomaso ED, Massacesi C, Saura C. Phase II study of buparlisib (BKM120) and trastuzumab in patients with HER2+ locally advanced or metastatic breast cancer resistant to trastuzumab-based therapy. Breast Cancer Res Treat 2018;168:357-364.

7. Yang $\mathrm{S}$, Li X, Guan W, Oian M, Yao Z, Yin X, Zhao H. NVP-BKM120 inhibits colon cancer growth via Fox03a-dependent PUMA induction. Oncotarget 2017;8:83052-83062.

8. Padthaisong $S$, Dokduang $H$, Yothaisong $S$, Techasen $A$, Namwat $N$, Yongvanit $\mathrm{P}$, Khuntikeo N, Titapun A, Sangkhamanon S, Loilome W. Inhibitory effect of NVP-BKM120 on cholangiocarcinoma cell growth. Oncol Lett 2018;16:1627-1633.

9. Safaroghli-Azar A, Bashash D, Kazemi A, Pourbagheri-Sigaroodi A, Momeny M. Anticancer effect of pan-PI3K inhibitor on multiple myeloma cells: Shedding new light on the mechanisms involved in BKM120 resistance. Eur J Pharmacol 2019;842:89-98.

10. Bashash D, Ghaffari SH, Zaker F, Kazerani M, Hezave $K_{1}$ Hassani $S$, Rostami M, Alimoghaddam K, Ghavamzadeh A. BIBR 1532 increases arsenic trioxidemediated apoptosis in acute promyelocytic leukemia cells: therapeutic potential for APL. Anticancer Agents Med Chem 2013;13:1115-1125.

11. Bayati S, Bashash D, Ahmadian S, Safaroghli-Azar A, Alimoghaddam $K$, Ghavamzadeh A, Ghaffari SH. Inhibition of tachykinin NK1 receptor using aprepitant induces apoptotic cell death and $\mathrm{G} 1$ arrest through Akt/p53 axis in pre-B acute lymphoblastic leukemia cells. Eur J Pharmacol 2016;791:274283.

12. Yu JS, Cui W. Proliferation, survival and metabolism: the role of PI3K/AKT/ mTOR signalling in pluripotency and cell fate determination. Development 2016;143:3050-3060.

13. Fiorentino FP, Tokgün E, Solé-Sánchez $S$, Giampaolo $S$, Tokgün 0 , Jauset T, Kohno T, Perucho M, Soucek L, Yokota J. Growth suppression by MYC inhibition in small cell lung cancer cells with TP53 and RB1 inactivation. Oncotarget 2016;7:31014-31028.

14. Karimian A, Ahmadi Y, Yousefi B. Multiple functions of p21 in cell cycle, apoptosis and transcriptional regulation after DNA damage. DNA Repair (Amst) 2016;42:63-71.
15. Bashash D, Delshad M, Riyahi N, Safaroghli-Azar A, Pourbagheri-Sigaroodi A, Momeny M. Inhibition of PI3K signaling pathway enhances the chemosensitivity of APL cells to ATO: proposing novel therapeutic potential for BKM120. Eur J Pharmacol 2018;841:10-18.

16. Wang J, Chu ESH, Chen HY, Man K, Go MYY, Huang XR, Lan HY, Sung JJY, Yu J. microRNA-29b prevents liver fibrosis by attenuating hepatic stellate cell activation and inducing apoptosis through targeting PI3K/AKT pathway. Oncotarget 2015;6:7325-7338.

17. Jin $X$, Jia $T$, Liu $R, X u S$. The antagonistic effect of selenium on cadmiuminduced apoptosis via PPAR- $\gamma /$ PI3K/Akt pathway in chicken pancreas. J Hazard Mater 2018;357:355-362.

18. Zhou MF, Feng ZP, Ou YC, Peng JJ, Li K, Gong HD, Qiu BH, Liu YW, Wang YJ, Qi ST. Endoplasmic reticulum stress induces apoptosis of arginine vasopressin neurons in central diabetes insipidus via PI3K/Akt pathway. CNS Neurosci Ther 2019:25:562-574.

19. Sheikh-Zeineddini N, Bashash D, Safaroghli-Azar A, Riyahi N, Shabestari RM, Janzamin E, Safa M. Suppression of c-Myc using 10058-F4 exerts caspase-3-dependent apoptosis and intensifies the antileukemic effect of vincristine in pre-B acute lymphoblastic leukemia cells. J Cell Biochem 2019;120:14004-14016

20. Vomero $M$, Manganelli $V$, Barbati $C$, Colasanti $T$, Capozzi $A$, Finucci $A$, Spinelli FR, Ceccarelli F, Perricone C, Truglia S, Morrone S, Maggio R, Misasi $R$, Bombardieri $M$, Di Franco $M$, Conti $F$, Sorice $M$, Valesini G, Alessandri C. Reduction of autophagy and increase in apoptosis correlates with a favorable clinical outcome in patients with rheumatoid arthritis treated with anti-TNF drugs. Arthritis Res Ther 2019;21:39.

21. Fleisher B, Mody H, Werkman C, Bihorel S. Chloroquine and osimertinib induce synergic reduction in cell viability through autophagy/apoptosis crosstalk. FASEB J 2019;33(Supp 1):675.13.

22. Knight T, Luedtke D, Edwards H, Taub JW, Ge Y. A delicate balance-The BCL2 family and its role in apoptosis, oncogenesis, and cancer therapeutics. Biochem Pharmacol 2019;162:250-261.

23. Bashash D, Delshad M, Safaroghli-Azar A, Safa M, Momeny M, Ghaffari SH. Novel pan PI3K inhibitor-induced apoptosis in APL cells correlates with suppression of telomerase: an emerging mechanism of action of BKM120. Int J Biochem Cell Biol 2017;91(Pt A):1-8.

24. Saleh R, Taha RZ, Sasidharan Nair V, Alajez NM, Elkord E. PD-L1 blockade by atezolizumab downregulates signaling pathways associated with tumor growth, metastasis, and hypoxia in human triple negative breast cancer. Cancers (Basel) 2019;11:1050

25. Milella M, Ciuffreda L, Bria E. Signal transduction pathways as therapeutic targets in cancer therapy. In: Reddy L, Couvreur P (eds). Macromolecular Anticancer Therapeutics. New York, Springer, 2010.

26. Hu Y, Guo R, Wei J, Zhou Y, Ji W, Liu J, Zhi X, Zhang J. Effects of PI3K inhibitor NVP-BKM120 on overcoming drug resistance and eliminating cancer stem cells in human breast cancer cells. Cell Death Dis 2015;6:e2020.

27. Zhong JT, Yu J, Wang HJ, Shi Y, Zhao TS, He BX, Qiao B, Feng ZW. Effects of endoplasmic reticulum stress on the autophagy, apoptosis, and chemotherapy resistance of human breast cancer cells by regulating the PI3K/AKT/mTOR signaling pathway. Tumour Biol 2017;39:1010428317697562.

28. Zhu J, Hou T, Mao X. Discovery of selective phosphatidylinositol 3-kinase inhibitors to treat hematological malignancies. Drug Discov Today 2015;20:988-994.

29. Allegretti $M$, Ricciardi $M R$, Licchetta $R$, Mirabilii $S$, Orecchioni $S$, Reggiani $F$, Talarico G, Foà R, Bertolini F, Amadori S, Torrisi MR, Tafuri A. The pan-class I phosphatidyl-inositol-3 kinase inhibitor NVP-BKM120 demonstrates antileukemic activity in acute myeloid leukemia. Sci Rep 2015;5:18137.

30. Pillinger G, Loughran NV, Piddock RE, Shafat MS, Zaitseva L, Abdul-Aziz A, Lawes MJ, Bowles KM, Rushworth SA. Targeting PI3K $\delta$ and PI3K $\gamma$ signalling disrupts human AML survival and bone marrow stromal cell mediated protection. Oncotarget 2016;7:39784-39795. 
31. Prasad SB, Yadav SS, Das M, Modi A, Kumari S, Pandey LK, Singh S, Pradhan $\mathrm{S}$, Narayan G. PI3K/AKT pathway-mediated regulation of p27 Kip1 is associated with cell cycle arrest and apoptosis in cervical cancer. Cell Oncol (Dordr) 2015;38:215-225.

32. Xie $C$, He $Y$, Zhen $M$, Wang $Y, X u Y$, Lou L. Puquitinib, a novel orally available

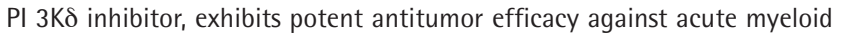
leukemia. Cancer Sci 2017;108:1476-1484.

33. Liang J, Slingerland JM. Multiple roles of the PI3K/PKB (Akt) pathway in cell cycle progression. Cell Cycle 2003;2:339-345.
34. Vanajothi R, Srinivasan P. An anthraquinone derivative from Luffa acutangula induces apoptosis in human lung cancer cell line $\mathrm{NCl}-\mathrm{H} 460$ through p53-dependent pathway. J Recept Signal Transduct Res 2016;36:292-302.

35. Bashash D, Safaroghli-Azar A, Delshad M, Bayati S, Nooshinfar E, Ghaffari $\mathrm{SH}$. Inhibitor of pan class-I PI3K induces differentially apoptotic pathways in acute leukemia cells: shedding new light on NVP-BKM120 mechanism of action. Int J Biochem Cell Biol 2016;79:308-317.

36. Trocoli A, Djavaheri-Mergny M. The complex interplay between autophagy and NF-кB signaling pathways in cancer cells. Am J Cancer Res 2011;1: 629-649. 